\title{
Prediksi Resistensi Udang Vaname (Litopenaus vannamei) terhadap Infectious Hypodermal and Hematopoietic Necrosis Virus (IHHNV) dari Tambak Intensif dan Semi Intensif Jepara Menggunakan Marka RAPD
}

\author{
Muhammad Mulyadi ${ }^{1}$, Christina Ratna Handayani ${ }^{2}$, Hermin Pancasakti Kusumaningrum ${ }^{1}$ \\ dan Anto Budiharjo ${ }^{1}$, \\ 1.Jurusan Biologi, Fakultas Sains dan Matematika, Universitas Diponegoro, Semarang 50275 Telepon (024) \\ 7474754; Fax. (024) 76480690 \\ 2.Laboratorium Biologi Molekuler, Manajemen Kesehatan Hewan Aquatik (MKHA), Balai Besar \\ Pengembangan Budidaya Air Payau (BBPBAP), Jepara. Telepon (0291)591125; Fax (0291)591724 \\ Email: kangmulyadie@yahoo.co.id
}

\begin{abstract}
Infectious Hypodermal and Hematopoietic Necrosis Infectious Virus (IHHNV) is the most important DNA virus which can lead to Runt Deformity Syndrome (RDS) in vaname shrimp. The RAPD technique can be used to determine the resistance of a species to a disease. This research aimed to screen and identify RAPD markers which could distinguish the resistance of vaname shrimp to IHHNV reared at intensive and semi-intensive pond. The DNA template was amplified by PCR using 5 primers : OPA 06, OPA 08, OPA 19, OPD-02 and OPZ-15. The results showed that only the primer OPA-19 and OPZ-15 were able to produce $100 \%$ polymorphic bands with sizes from 400-1700 bp as well as showing the resistance IHHNV in vaname shrimp. Based on these results, vaname shrimp which reared at the intensive pond were more resistant to IHHNV compared with the semi-intensive pond.
\end{abstract}

Key words: RAPD, shrimp vaname, IHHNV, intensive \& semi-intensive pond

\begin{abstract}
Abstrak
Infectious Hypodermal and Hematopoietic Necrosis Virus (IHHNV) merupakan penyakit viral yang mengakibatkan kekerdilan pada tubuh udang vaname. Teknik Random Amplified Polymorphisms DNA (RAPD) merupakan teknik perbanyakan DNA menggunakan marka molekuler tertentu melalui reaksi Polymerase Chain Reaction (PCR). Teknik tersebut dapat digunakan untuk memprediksi resistensi suatu spesies terhadap suatu penyakit. Penelitian ini bertujuan untuk menyeleksi dan mengidentifikasi marka RAPD pembeda udang vaname resisten atau rentan terhadap IHHNV serta untuk memprediksi resistensi udang vaname yang dipelihara di tambak intensif dan semi intensif terhadap IHHNV. DNA cetakan udang vaname diamplifikasi menggunakan 5 jenis primer RAPD yaitu OPA-06, OPA-08, OPA-19, OPD-02 dan OPZ-15. Hasil penelitian menunjukkan hanya primer OPA-19 dan OPZ-15 yang mampu menghasilkan pita polimorfik 100\% dengan ukuran berkisar 400-1.700 pb. Kedua primer tersebut mampu menunjukkan resistensi udang vaname terhadap IHHNV. Udang vaname yang dipelihara di tambak intensif memperlihatkan resistensi yang lebih tinggi terhadap IHHNV dibandingkan dengan tambak semi intensif.
\end{abstract}

Kata kunci : RAPD, udang vaname, IHHNV, tambak semi intensif, intensif 


\section{PENDAHULUAN}

Udang vaname merupakan salah satu komoditas unggulan sektor perikanan di Indonesia. Masalah utama yang dihadapi dalam pengembangan budidaya udang vaname adalah penyakit viral yang sampai saat ini belum dapat diatasi sampai tuntas (Dwinanti, 2006). Infectious Hypodermal and Hematopoetic Necrosis Virus (IHHNV) merupakan salah satu jenis virus yang menyerang tambak udang vaname secara luas di

Teknik PCR merupakan cara terbaik untuk mendeteksi agen infeksi yang sulit ditemukan (Campbell et al., 2010). Teknik ini dibutuhkan sebagai metode deteksi dini beberapa jenis agen penyakit seperti virus dan sebagai upaya pencegahan dan pengendalian penyakit sehingga tidak terjadi kematian yang tidak terkendali pada budidaya udang vaname (Sriwulan et al., 2012).

Teknik RAPD merupakan teknik biologi molekuler yang secara ekstensif dapat digunakan untuk mengidentifikasi marka genetik tertentu untuk menguji resistensi suatu hewan atau tumbuhan terhadap suatu penyakit (Karp et al., 1996). Hizer et al. (2002) berhasil memprediksi resistensi udang L. stylirostris terhadap IHHNV menggunakan marka RAPD.

Penelitian ini bertujuan untuk menyeleksi dan mengidentifikasi primer RAPD pembeda udang vaname (L. vannamei) resisten atau rentan terhadap IHHNV dan untuk memprediksi resistensi antara udang vaname yang dibudidayakan di tambak semi intensif dan tambak intensif terhadap IHHNV.

\section{Materi dan Metode \\ Bahan Penelitian}

Bahan yang digunakan dalam penelitian ini antara lain adalah udang vaname, fenol, Proteinase $K(10 \mathrm{mg} / \mathrm{mL})$, sodium dodesil sulfat (sds) 1\%, kloroform: isoamil alkohol (24:1 v/v), alkohol absolut, alkohol 95\%, alkohol 70\%, nuclease free water, $5 \mathrm{X}$ PCR bufer, $50 \mathrm{~mm}$ $\mathrm{MgCl}_{2}, 200 \mathrm{M}$ dNTP mix, Taq DNA polymerase, Tris-HCl, 0,5 M EDTA pH 8, agarosa, EtBr (10 $\mathrm{mg} / \mathrm{mL}$ ), loading buffer, Tris Boric EDTA, $100 \mathrm{pb}$ DNA Ladder, akuades, akuabides, $\mathrm{NaOH}$, primer untuk deteksi IHHNV: primer forward 389F dan primer reverse 389R (SNI, 2009), Primer RAPD: OPA-06, OPA-08, OPA-19, OPD-02 dan OPZ-15 (Hizer et al., 2002).

\section{Pembuatan Inokulum IHHNV}

Inokulum IHHNV $(20 \mathrm{mg} / \mathrm{ml})$ dibuat dengan cara menggerus 1 gram insang dan kaki renang udang vaname positif IHHNV dan dilarutkan dalam $10 \mathrm{~mL}$ air laut steril (konsentrasi 10\%), berbagai negara. Penyakit IHHNV menyebabkan udang menjadi kerdil atau Runt Deformity Syndrome (RDS) dan berbagai cacat kutikula udang khususnya pada daerah rostum, antenna, dada dan abdomen (Kalagayan et al. 1991). Penyakit IHHNV dapat menyerang semua stadia hidup udang, baik telur, larva, post larva, juvenil maupun stadia dewasa. Udang yang telah sembuh dapat menjadi carier IHHNV sepanjang hidupnya (Motte at al., 2003).

suspensi disentrifugasi sebanyak dua kali dengan kecepatan $3000 \mathrm{~g}$ selama 20 menit dan $8000 \mathrm{~g}$ selama 30 menit, kemudian suspensi disaring dengan kertas saring miliophore $0,45 \mathrm{~m}$ (Hameed et al.,1998).

\section{Inokulasi IHHNV dan Uji Tantang Udang Vaname}

Penelitian ini dibuat dengan 3 jenis perlakuan dengan jumlah ulangan tiap perlakuan sebanyak 3 ekor udang vaname. Uji tantang dilakukan selama 6 hari dalam akuarium. Perlakuan tersebut antara lain:

a) Udang vaname asal tambak intensif A1 dan A2 BBPBAP Jepara sebagai kontrol negatif IHHNV;

b) Udang vaname asal tambak semi intensif dari daerah Mlonggo Jepara. Sampel tersebut sudah terdeteksi positif terinfeksi IHHNV sejak pertama kali diambil dari tambak.

c) Udang vaname asal tambak intensif A1 dan A2 BBPBAP Jepara (negatif IHHNV) yang diinjeksi dengan inokulum IHHNV sebanyak $30 \mathrm{~L}$ di antara ruas ekor udang bagian kedua atau ketiga.

\section{Ekstraksi DNA Udang Vaname}

Ekstraksi DNA udang vaname yang telah diujitantang dilakukan dengan menggunakan metode fenol (OIE, 2009 dan SNI, 2009).

\section{Amplifikasi DNA Udang Vaname untuk Mendeteksi IHHNV (SNI, 2009).}

Total volume untuk tiap master mix PCR adalah sebanyak $25 \mu \mathrm{L}$ yang terdiri dari: 15,875 $\mathrm{L}$ destilated water, 5 L $5 \mathrm{x}$ PCR bufer, 1,5 L $25 \mathrm{mM} \mathrm{MgCl} 2,0,5 \quad$ L dNTP mix (10mM), 0,5 L primer $389 \mathrm{~F}(10 \mathrm{mM}) \quad 0,5 \mathrm{~L}$, primer $389 \mathrm{R}$ $(10 \mathrm{mM}) \quad$ (Tabel 1), 0,125 L Taq DNA polymerase dan 1 L DNA cetakan. Pengaturan suhu PCR: inisiasi denaturasi $\left(95^{\circ} \mathrm{C}, 5\right.$ menit), denaturasi $\left(95^{\circ} \mathrm{C}, 30\right.$ detik), annealing $\left(55^{\circ} \mathrm{C}, 30\right.$ detik), inisiasi elongasi $\left(72^{\circ} \mathrm{C}, \quad 1\right.$ menit) dan final elongasi $\left(72^{\circ} \mathrm{C}, 7\right.$ menit $)$. Siklus diulang sebanyak $35 \mathrm{x}$. 
Tabel 1. Primer yang digunakan untuk mendeteksi IHHNV (OIE, 2009).

\begin{tabular}{cc}
\hline $\begin{array}{c}\text { Pri } \\
\mathrm{m}\end{array}$ & Urutan Basa Primer \\
er & $\left(5^{\prime}\right.$ ke $\left.3^{\prime}\right)$ \\
\hline 38 & CGG AAC ACA ACC CGA CTT TA \\
9 & \\
F & \\
38 & GGC CAA GAC CAA AAT ACG AA \\
9 & \\
R & \\
\hline
\end{tabular}

\section{Amplifikasi DNA menggunakan Marka RAPD- PCR (Hizer et al., 2002)}

Total volume untuk tiap master mix RAPDPCR adalah sebanyak $30 \mathrm{~L}$ yang terdiri dari: $14,75 \quad \mathrm{~L} \mathrm{H}_{2} \mathrm{O}, 5$ L $5 \mathrm{X}$ PCR Buffer, 2,5 L $\mathrm{MgCl}_{2}, 0,5$ L dNTP mix, 1 L primer RAPD (Tabel 2), 0,25 L Taq DNA polimerase dan 1 L DNA cetakan. Pengaturan suhu PCR thermocycler antara lain: inisiasi denaturasi $\left(95^{\circ} \mathrm{C}, 2\right.$ menit), denaturasi $\left(94^{\circ} \mathrm{C}, 40\right.$ detik), annealing $\left(37^{\circ} \mathrm{C}, 45\right.$ detik), inisiasi elongasi $\left(72^{\circ} \mathrm{C}, 1,5\right.$ menit) dan final elongasi $\left(72^{\circ} \mathrm{C}, 7\right.$ menit). Siklus diulang sebanyak 40 x. Produk hasil amplifikasi selanjutnya dielektroforesis menggunakan $2 \%$ gel agarosa dengan $0,5 \mathrm{~g} / \mathrm{mL}$ EtBr pada voltase $30-35 \mathrm{~V}$ selama 2,5 jam.

Tabel 2. Primer RAPD untuk memprediksi resistensi udang vaname terhadap IHHNV (Hizer et al., 2002).

\begin{tabular}{ccccc}
\hline Primer & $\begin{array}{c}\text { Ukuran } \\
(\mathrm{pb})\end{array}$ & $\begin{array}{c}\text { Urutan } \\
\text { basa Primer } \\
\left(5^{\prime}-3^{\prime}\right)\end{array}$ & $\begin{array}{c}\% \\
\text { GC }\end{array}$ & $\begin{array}{c}\text { Tm } \\
\left({ }^{0} \mathrm{C}\right)\end{array}$ \\
\hline OPA-06 & 990 & GGTCCCTGAC & 70 & 34 \\
OPA-08 & 600 & GTGACGTAGG & 60 & 32 \\
OPA-19 & 875 & CAAACGTCGG & 60 & 32 \\
OPD-02 & 850 & GGACCCAACC & 70 & 34 \\
OPZ-15 & 790 & CAGGGCTTTC & 60 & 32 \\
\hline
\end{tabular}

\section{Analisis Data}

Hasil amplifikasi PCR yang telah dielektroforesis berupa pita-pita dianalisis secara kualitatif dan kuantitatif. Analisis kualitatif dilakukan dengan cara menghitung kisaran ukuran pita DNA, jumlah pita yang teramplifikasi dan persentase pita polimorfik dan monomorfik. Analisis secara kuantitatif dilakukan dengan cara skoring pita yang muncul yang akan diterjemahkan ke dalam data biner. Penerjemahan data biner didasarkan ada atau tidaknya pita yang terbentuk, nilai 1 untuk pita yang muncul dan 0 bila tidak ada pita yang muncul.

\section{Hasil dan Pembahasan}

Berdasarkan hasil pengamatan gejala klinis yang dilakukan selama masa uji tantang, perubahan tingkah laku dan morfologi udang vaname hanya terjadi pada sampel yang berasal dari tambak semi intensif (positif IHHNV) dan tambak intensif yang diinjeksi dengan IHHNV (Tabel 3). Perubahan tingkah laku udang vaname tersebut sama halnya seperti yang disebutkan oleh Lightner et al. (1996) udang yang terserang IHHNV akan menunjukkan gejala klinis berupa udang sering naik ke permukaan air, jarang bergerak dan sering berputar-putar sebelum akhirnya tenggelam ke dasar tambak, kulit udang akan terlihat putih keruh dan rostum yang membengkok. Penurunan aktivitas gerak diduga akibat dari kurangnya energi, sebab respon terhadap pakan mengalami penurunan sehingga pasokan energi untuk aktivitas berkurang.

\section{BAHAN DAN METODE \\ Lokasi Penelitian.}

Lokasi penelitian adalah sawah organik yang ditanami padi terus menerus sepanjang tahun, seluas 1 hektar bersertifikat nasional, terletak di Desa Bakalrejo Kecamatan Susukan Kabupaten Semarang (Kelompok Tani : Green Grow).

Penelitian ini merupakan bagian dari penelitian disertasi yang sedang dilaksanakan. Pada penelitian disertasi yang dilakukan data diambil dalam rentang waktu tiga kali tanam padi secara berturutan selama satu tahun, sedang penelitian ini mengambil bagian di musim tanam ketiga.

\section{Cara Kerja}

Untuk mengetahui keragaman jenis dan kelimpahan populasi penggerek batang padi dan serangga lain berpotensi hama nokturnal di lokasi penelitian serta fluktuasinya dari waktu ke waktu, dilakukan pengambilan sampel serangga dewasa pada tanaman padi fase vegetatip dan fase generatip di ekosistem sawah organik pada waktu 
malam hari. Pengamatan dan pengambilan sampel serangga dewasa dilakukan setiap 2 minggu sekali selama musim tanam padi sejak pindah tanam. Pengambilan sampel penggerek batang padi dan serangga lain berpotensi hama dewasa menggunakan 5 buah perangkap lampu yang dipasang secara diagonal di tengah-tengah areal sawah sepanjang malam (dipasang mulai menjelang malam hingga pagi hari), dengan frekuensi pengambilan satu kali pada pagi hari. Sampel penggerek batang padi dan serangga lain berpotensi hama dewasa yang diperoleh dikoleksi dalam botol koleksi berisi alkohol $70 \%$ dan diberi label nomer koleksi, waktu pengambilan, lokasi pengambilan dan kondisi cuaca. Pengambilan sampel penggerek batang padi dan serangga lain berpotensi hama diurnal dewasa menggunakan jaring ayun pada 5 titik secara diagonal di tengahtengah areal sawah (mengikuti titik diagonal perangkap lampu), dengan frekuensi pengambilan satu kali pada pagi hari (Dent \& Walton, 1997; Direktorat Perlindungan Tanaman Pangan Direktorat Jendral Tanaman Pangan - Departemen Pertanian, 2008).

Keragaman jenis dihitung dengan menggunakan rumus Shannon Wiener $\left(\mathrm{H}^{\prime}=\right.$ $\sum($ ni/N ln ni/N) (Brower, Zar \& von Ende. 1997). Kelimpahan jenis dihitung secara relatif dengan menggunakan rumus $\mathrm{Di}=\mathrm{ni} / \mathrm{N} \times 100 \%$. Data kelimpahan jenis ini dapat digunakan untuk menghitung dominansi jenis. Pemerataan persebaran dihitung menggunakan indks pemerataan persebarab e $=\mathrm{H}^{\prime} / \mathrm{H}$ max (Brower, Zar \& von Ende. 1997).

\section{HASIL DAN PEMBAHASAN}

1. Keragaman jenis penggerek batang padi

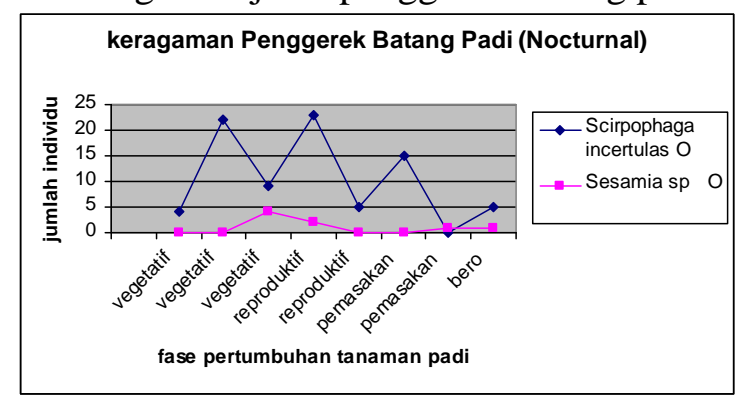

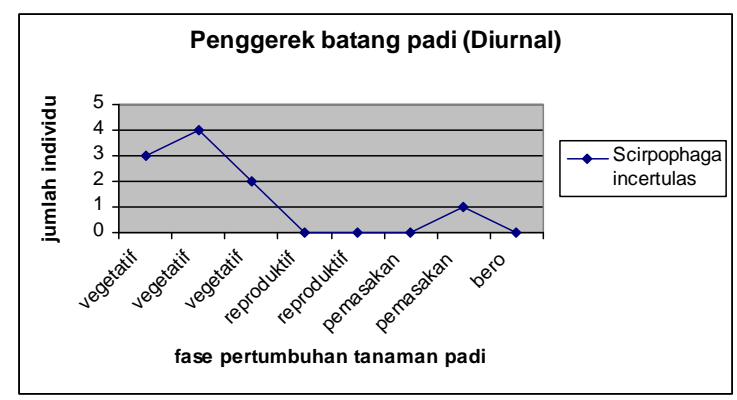

Gambar 1. Jenis penggerek batang padi yang ditemukan

Jenis penggerek batang padi yang ditemukan di ekosistem sawah organik (Gambar 1) adalah penggerek batang padi kuning Scircophaga incertulas yang tertangkap dengan light traps (nocturnal) maupun sweep net (diurnal), sedangkan penggerek batang padi merah jambu Sesamia inferens hanya tertangkap dengan light traps. Penggerek batang padi kuning dapat dijumpai berfluktuasi pada semua fase pertumbuhan tanaman padi. Sedangkan penggerek batang padi merah jambu hanya dijumpai kadangkadang dengan jumlah yang sedikit.

2. Keragaman jenis serangga berpotensi hama

Jenis serangga lain berpotensi hama yang ditemukan di ekosistem sawah organik yang tertangkap dengan light trap berkisar antara 10 20 jenis, keragaman jenis tertinggi pada fase pertumbuhan tanaman padi generatip, sedangkan yang tertangkap dengan sweep net berkisar antara $15-25$ jenis dengan keragaman jenis tertinggi pada awal fase generatif pertumbuhan tanaman padi (Gambar 2). Jenis serangga yang berpotensi hama pada ekosistem sawah organik antara lain adalah jenis-jenis grasshopper (Acrididae, Tettigonidae), planthopper (Cicadellidae), leafhopper (Delphacidae), rice ear bug (Alydidae) dan rice stem borrer (Noctuidae). 

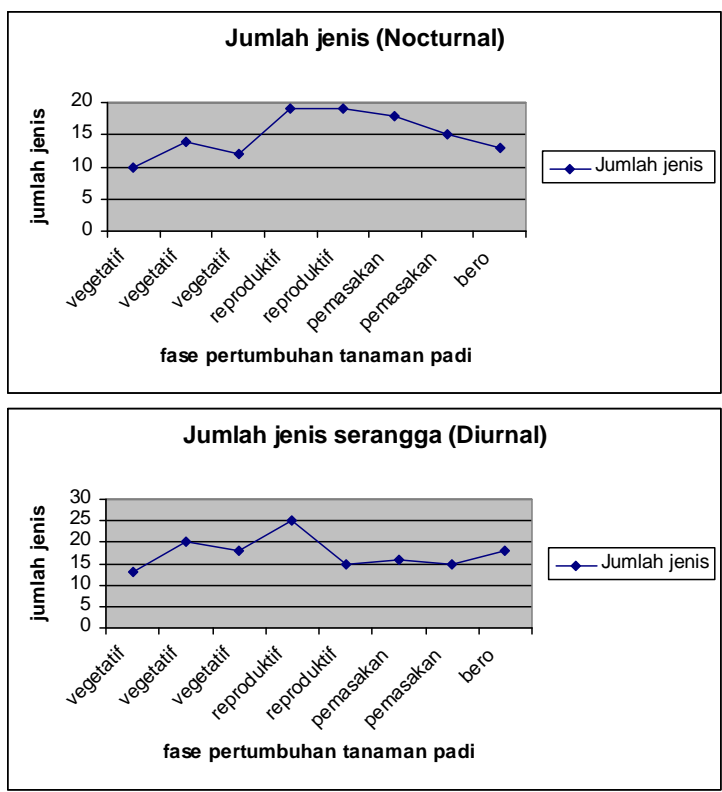

Gambar 2. Keragaman jenis serangga hama di ekosistem sawah organik

3. Kelimpahan serangga berpotensi hama
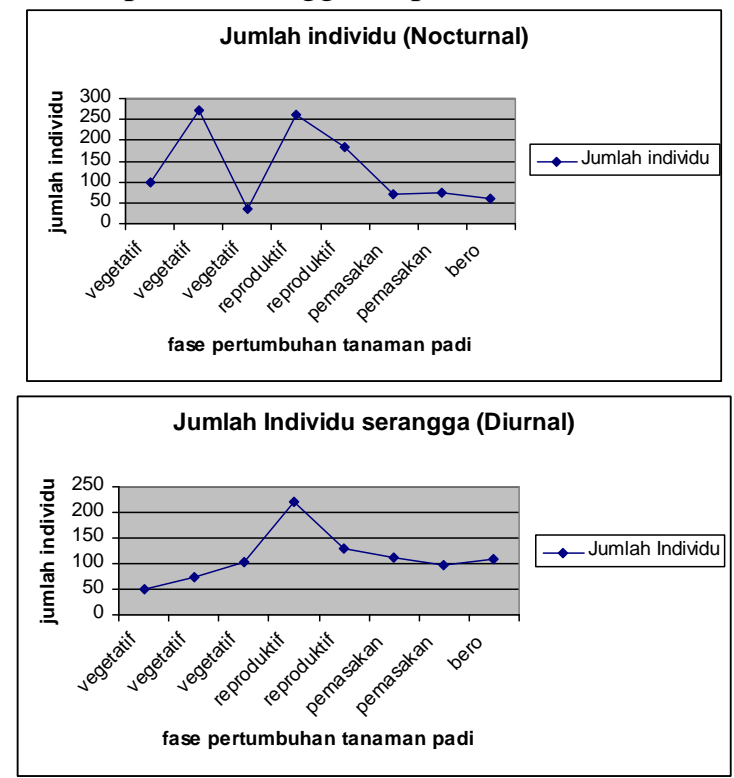

Gambar 3. Kelimpahan populasi serangga berpotensi hama di ekosistem sawah organik

Kelimpahan individu populasi serangga berpotensi hama di ekosistem sawah organik yang tertangkap dengan light trap berfluktuasi, berkisar antara $50-250$ individu. Kelimpahan individu meningkat pada pertengahan fase vegetatip tanaman padi dan kemudian menurun pada akhir fase vegetatif, selanjutnya meningkat lagi pada awal fase reproduktif tanaman padi kemudian menurun sampai akhir fase pemasakan (panen) tanaman padi. Sedangkan dengan sweep net, kelimpahan individu populasi serangga berpotensi hama berkisar antara $50-200$ individu. Kelimpahan individu sejak awal fase vegetatif tanaman padi meningkat hingga awal fase reproduktif tanaman padi, yang selanjutnya akan terus menurun hingga akhir fase pemasakan (panen) tanaman padi (Gambar 3).

\section{Indeks H' dan indeks e}

Pada Gambar 4 nampak bahwa indeks keanekaragaman jenis (H') serangga berpotensi hama pada ekosistem sawah organik relatif tinggi berkisar antara 1,5 - 2,5, dan hampir sama dari waktu ke waktu selama fase pertumbuhan tanaman padi, baik yang tertangkap dengan light trap maupun yang tertangkap dengan sweep net. Ini berarti bahwa pada ekosistem sawah organik tersebut cukup stabil dalam menunjang kehidupan serangga bepotensi hama, yang dikarenakan oleh kontinuitas penanaman padi sepanjang tahun dengan 3 kali musim tanam padi tanpa sela. Bagi serangga berpotensi hama tanaman padi, sistem tanam padi-padi-padi sepanjang tahun tanpa sela, akan menjadi peluang untuk hadir secara kontinu dalam memperoleh energi.

Indeks pemerataan persebaran individu (Gambar 4) serangga-serangga berpotensi hama pada ekesistem sawah organik juga relatif tinggi, berkisar antara 0,6-0.9, yang mengindikasikan bahwa persebaran inidividu dalam jenis relatif merata sehingga tidak ada dominansi jenis terhadap jenis yang lain. Mereka dapat memanfaatkan tanaman padi organik tersebut untuk membangun besar populasi secara bersamasama dengan peluang yang sama, dengan demikian tidak ada dominansi satu jenis terhadap jenis lainnya. 

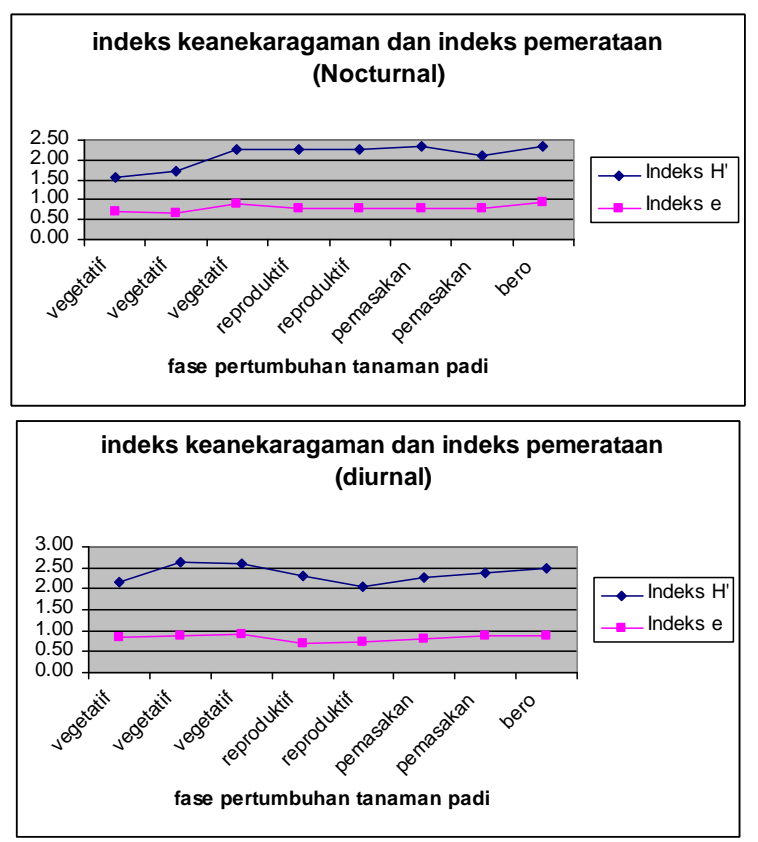

Gambar 4. Indeks keanekaragaman dan indeks pemerataan persebaran populasi serangga berpotensi hama di ekosistem sawah organik

\section{KESIMPULAN}

1. Penggerek batang padi yang ditemukan adalah penggerek batang padi kuning dan kadangkadang penggerek batang padi merah jambu

2. Keanekaragaman serangga berpotensi hama di ekosistem sawah organik relatif tinggi terutama pada saat tanaman padi memasuki fase reproduktif

3. Kelimpahan populasi serangga berpotensi hama di ekosistem sawah organik relatif melimpah terutama pada saat tanaman padi memasuki fase reproduktif

4. Keanekaragaman jenis dan kelimpahan populasi serangga berpotensi hama pada ekosistem sawah organik relatif stabil dan merata persebarannya.

\section{UCAPAN TERIMA KASIH}

Penulis mengucapkan banyak terima kasih pada Direktorat Penelitian dan Pengabdian Kepada Masyarakat Direktorat Jenderal Pendidikan Tinggi (DitlitabmasDikti) Kementerian Pendidikan dan Kebudayaan, Tahun Anggaran 2013, melalui
Daftar Isian Pelaksanaan Anggaran (DIPA) Universitas Diponegoro Nomor DIPA023.04.2.189815/2013 tanggal 05 Desember 2012.

\section{DAFTAR PUSTAKA}

Brower, Zar \& von Ende. 1997. Field and Laboratory Methods for General Ecology. WCB. McGraw Hill. Boston.

Dent \& Walton, 1997. Methods in Ecological and Agricultural Entomology. CAB International.

Direktorat Perlindungan Tanaman Pangan Direktorat Jenderal Tanaman Pangan Departemen Pertanian. 2008. Pedoman Pengamatan Dan Pelaporan Perlindungan Tanaman Pangan. Departemen Pertanian. Jakarta.

Hattori and Siwi, 1986. Rice Stem Borers in Indonesia. Dalam Direktorat Jendral Pertanian Tanaman Pangan, Direktorat Bina Perlindungan Tanaman (2007) Pedoman Teknis Pengendalian Hama dan Penggerek Batang Padi. Departemen Pertanian, Jakarta.

IFOAM, 2005. Principles of Organic Abriculture. International Federation of Organic Agriculture Movements (IFOAM). Germany

Kalshoven, LGE, 1981. The pest of crops in Indonesia. PT Ichtiar Baru, Jakarta

Kunia, K, 2011. Pertanian Organik, teknologi ramah http://kunia.wordpress.com.

Mutiarawati, T, 2006. Kendala dan Peluang Dalam Produksi Pertanian Organik di Indonesia. Makalah Ilmiah Fakultas Pertanian Universitas Padjadjaran Bandung

Siwi, SS. 1979. Identifikasi Penggerek Batang Padi Di Indonesia. Konggres Entomologi I. Jakarta

Soehardjan, M. 1983. Dinamika Populasi Penggerek Kuning Padi Tryporiza incertulas (Walker) (Pyralidae, Lepidoptera). Disertasi Institut Teknologi Bandung.

Soejitno, J. 1986. Pengaruh Serangan Penggerek Padi Kuning Tryporiza incertulas (Walker) Pada Berbagai Umur Tanaman Terhadap Kerusakan Tanaman Padi. Lembaga Penelitian Pertanan. Bogor. 
Standar Nasional Indonesia. 2002. Sistem Pangan Organik. SNI 01-6729-2002.

Sutanto, R, 2002. Pertanian Organik, menuju pertanian alternatif dan berkelanjutan. Kanisius Yogyakarta.

Sutarna, 1999. Perkembangan Populasi Penggerek Batang Padi Scirpophaga incertulas (Walker) Pada Tanaman Padi Oryza sativa
L. Var IR-64 Pada Pertanaman Musim Hujan di Banguntapan Bantul. Tesis Fakultas Biologi UGM.

Urip S, 2009. Pengembangan model peramalan hama penggerek batang padi kuning. http://saungurip.blogspot.com. 